\title{
Húsfogyasztási szokások egy naplóíró kutatás tapasztalatai alapián
}

\author{
Keller Veronika - Ercsey Ida \\ Széchenyi István Egyetem
}

\begin{abstract}
A TANULMÁNY CÉLJA
Hazánkban a hús egy nagyon fontos élelmiszerforrás, hiszen az élelmiszerfogyasztási statisztikák alapján a 4. helyen áll. A tanulmány célja a lakosok étkezési szokásának megismerése és a hús szerepének feltárása a mindennapokban, valamint a fogyasztók szegmentálása az étkezések a húsfogyasztás és a nassolás gyakorisága alapján, továbbá az azonosított fogyasztói csoportok profilozása szocio-demográfiai ismérvek alapján.
\end{abstract}

\begin{abstract}
ALKALMAZOTT MÓDSZERTAN
A kutatási kérdések megválaszolásához a naplóírás módszerét alkalmaztuk. A kutatásban résztvevők egy héten át jegyzetelték, hogy mikor, mit és hol ettek, illetve az étkezések között nassoltak-e. Az empirikus kutatás 2017 áprilisában zajlott hazánk legfejlettebb régióiban (Nyugat-Dunántúl: 66,7\%, Közép-Dunántúl és Közép-Magyarország: 33,3\%). 171 fogyasztót sikerült elérni, 64,9\%-ban nőket, 35,1\%-ban férfiakat. Az eredmények interpretálásához egy- és többváltozós statisztikai módszereket alkalmaztunk. A fogyasztással kapcsolatos szocio-demográfiai összefüggéseket varianciaelemzéssel teszteltük. A fogyasztók szegmentálását hierarchikus és K-közép klaszterelemzéssel folytattuk le. Az egyes klaszterek profilozását multinominális logisztikus regresszióelemzés segítségével végeztük el.
\end{abstract}

\section{LEGFONTOSABB EREDMÉNYEK}

A vizsgált egyének számára az ebéd és a vacsora a legfontosabb étkezés, az ajánlott napi ötszöri étkezést csupán kevesen tartják be. A hús fontos a mindennapi étkezések alkalmával, bár a nők kevesebbszer fogyasztanak húst, mint a férfiak. A nassolás jelen van az emberek mindennapjaiban, főként az alacsonyabb iskolai végzettségüek körében. A heti étkezés, a húsfogyasztás és a nassolás gyakorisága alapján klaszterelemezést végzünk. Négy fogyasztói szegmenset azonosítottunk: a visszafogott húsevők, a tudatosan étkezők, a nassolók és a húsimádók csoportját. A visszafogott húsevők inkább nők, a tudatosan étkezők jellemzően falvakban és városokban laknak, csakúgy, mint a nassolók, akik alapfokú iskolai végzettségủek.

\section{JAVASLATOK}

A kutatás eredményei hasznosak lehetnek az élelmiszeripar, különösen a húsipari vállalatok számára, hogy célzott marketingkampánnyal és termékekkel érjék el a fogyasztókat.

Kulcsszavak: húsfogyasztás, nassolás, szegmentálás

Köszönetnyilvánitás: A publikáció a Széchenyi István Egyetem által az EFOP 3.6.1-16-2016-00017 „Nemzetköziesítés, oktatói, kutatói és hallgatói utánpótlás megteremtése, a tudás és technológiai transzfer fejlesztése, mint az intelligens szakosodás eszközei a Széchenyi István Egyetemen” címü uniós projekt keretében készült.

DOI: /10.15170/MM.2020.54.KSZ.III.04 


\section{BEVEZETÉS INTRODUCTION}

A világ húsfogyasztása 2017-ben jelentős eltéréseket mutatott az Egyesült Nemzetek Szervezetének Élelmezésügyi és Mezőgazdasági Szervezete (FAO) által készített statisztikák alapján. 2017ben az USA-ban ( $98,6 \mathrm{~kg} /$ fö/év), Ausztráliában (94,6 kg/fö/év) és Argentínában (91,4kg/fö/év) fogyasztották a legtöbb húst. Az Európai Unióban az egy före jutó fogyasztás $69,6 \mathrm{~kg}$ volt, ezzel a 10 . helyet érte el a világ országainak listáján (OECD 2019). Magyarországon ez az érték (61,1 kg/fó/év) kicsivel elmaradt 2017-ben. Hazánkban a cereáliák $(86,3 \mathrm{~kg} / \mathrm{fö} / \mathrm{év})$, illetve a zöldség és burgonya ( $81,8 \mathrm{~kg} /$ fö/év) voltak a legfőbb élelmiszerforrások, majd ezeket követték a tejtermékek $(73,4 \mathrm{~kg} /$ fö/év) és a húsfélék ${ }^{1}$. A jobb anyagi körülmények (10. decilis: $68,5 \mathrm{~kg}$ /fö/év) között élők több húst fogyasztottak, mint az alacsonyabb társadalmi státuszúak (1. decilis: 49,7 kg/fö/év). A húsfogyasztásban jelentős regionális különbségek mutatkoztak, a legtöbbet Dél-Alföldön (75,2 kg/fö) és a Dél-Dunántúlon (70,0 kg/fö) fogyasztották, a legkevesebbet pedig Magyarország legfejlettebb régióiban, Közép-Magyarországon (53,9kg/fö), illetve Nyugat-Dunántúlon (46,8kg/fö). Településtípus alapján pedig elmondható, hogy minél feljebb megyünk a hierarchiában, annál kevesebb húst fogyasztottak az ott élők, Budapesten 49,7 kg-ot, a megyei jogú városokban $55,2 \mathrm{~kg}$-ot, a városokban 62,2 kg-ot és a községekben 70,1 kg-ot (KSH 2017).

\section{SZAKIRODALMI ÁTTEKINTÉS ÉS MÓDSZERTAN LITERATURE REVIEW AND METHODOLOGY}

Töröcsik és Pál (2015) nagymintás kutatást végeztek az ételfogyasztói magatartás azon belül is a reggelizési szokások feltérképezésére. A szerzők rávilágítottak, hogy az étkezési alkalmak száma, jelentősége megváltozott, a fogyasztók egyre többször részesítik előnyben a gyorsan, akár más tevékenységeket végezve is fogyasztható ételeket. Felborultak a szokásos táplálkozási módok és sok esetben jellemző a rendszertelen étkezés. A táplálkozáson belül a reggeli mint téma különösen érdekessé vált az utóbbi időben. A megkérdezettek többsége naponta fogyaszt reggelit, de az ebédet tartják a fóétkezések közül a legfontosabbnak. A reggelire fogyasztott termékeket vizsgálva megállapítható, hogy hagyományos összeállításokat kedvel a lakosság többsége, a péktermékeket, felvágottat, szalámit. A reggeli fogyasztásának tipikus helyszíne az otthon, de megfigyelhetőek a kor szerinti, a generációs, illetve a lakóhely szerinti különbségek.

A húsfogyasztással kapcsolatban több empirikus tanulmány készült az elmúlt időszakban. Fehér és Szakály $(2018,444)$ reprezentatív kutatásaik során úgy találták, hogy a baromfi-és a sertéshús fogyasztása a legjellemzőbb a magyarokra. A húsfélék kedveltségéről pedig elmondható, hogy a csirkehús $(4,68)$ és a sertéshús $(4,37$ ötfokozatú skálán mérve) vezetik a listát. A sertéshúst a férfiak jobban kedvelik, mint a nők (Nábrádi és tsai 2017) és a megítélése az életkor előrehaladtával javul. Marketing szempontból célszerủ vizsgálni, hogy milyen fogyasztói csoportok különíthetők el a húsfogyasztás alapján. A hazai szakirodalomban korábban az attitüd alapú szegmentálást végezték el a húsfogyasztással kapcsolatban. Az affektív attitüd alapján elkülönítették a húsimádók $(50,4 \%)$, a fehér húst preferálók (14,4\%) a mindenevők (32,4\%) és a vegák $(2,8 \%)$ csoportját (Dernóczy-Polyák - Keller 2016). Szocio-demográfiai ismérvek alapján egyedül a nem estében tudtak szignifikáns összefüggést kimutatni. Később a húshoz kapcsolódó kötődés, függőség, jogosultság és hedonizmus alapján három fogyasztói klaszter (a húsevők, a semlegesek és a funkcionális húsevők) kerültek azonosításra egy nemzetközileg kifejlesztett skála tételei alapján (Dernóczy-Polyák - Keller 2018).

Az étkezéssel és a hússal kapcsolatos fogyasztási mintázatok vizsgálatában különböző nézöpontokkal találkozunk a nemzetközi szakirodalomban. Dagevos és Voordouw (2013) arra hívja fel a figyelmet, hogy az étkezési szokások és az élelmiszerfogyasztás hatással van a fenntarthatóság környezeti tényezöire. A kutatók konszenzusra jutottak a húsfogyasztást illetően, melynek lényege, hogy a növényi eredetủ élelmiszerek fogyasztása előnyösebb az állati eredetủ élelmiszerekhez képest, környezeti és energiahatékonysági megfontolások alapján (Marlow et al. 2009, Tukker et al. 2011). Ebböl kiindulva, a húsfogyasztás csökkentése is lényeges kérdés a fenntarthatóbb étrend és az élelmiszerek ökológiai lábnyomának mérséklése érdekében. Több nemzetközi kutatás fókuszált a különbözö nemzetek (norvégok, angolok, írek, hollandok) klaszterezésére húsfogyasztás alapján. Dagevos és Voordouw (2013) a holland lakosokat öt homogén szegmensbe sorolta. A tudatos flexitáriánusok jellemzően nők és felsőfokú végzettségüek. A húsfogyasztás csökkentése kérdésében ők a legaktívabbak, aminek hátterében elsősorban az etikai megfontolás, az egyéni egészség és a személyes norma áll. A ,szabad” 
húsevök gyakran fogyasztanak húst, de nyitottak a hús helyettesítésére és nem áll szándékukban a húsfélék csökkentése. A húsimádók sem akarják mérsékelni a húsfogyasztást, közöttük több a férfi (62\%) és ők megerősítik azt a sztereotípiát, amely szerint a húsevés maszkulin tevékenység. A fiatal válaszadók speciális megfontolásból (presztízs) vonzódnak a hús csökkentéséhez, ugyanakkor a húsevést fontosnak tekintik az egészségük szempontjából. Ez a csoport az extrovertált flexitáriánus klaszterhez tartozik. Végül a nem tudatos flexitáriánusok pozitívan viszonyulnak a vegetáriánus ételekhez és a húsfogyasztást nem tartják fontosnak az egészség, az etikai kérdések és a társadalmi státusz alapján. Ebben a klaszterben hasonló arányban vannak férfiak és nők, valamint a magas iskolai végzettségüek alulreprezentáltak. Verbeke és Vackier (2004) négy csoportba különítették el a hetente legalább egyszer húst fogyasztókat érintettségük (iz, egészség fontossága, tápanyagtartalom, kockázat) alapján: egyszerü húsimádók, akik naponta fogyasztanak friss húst és örömöt lelnek benne. Az óvatos húsimádók családosok, szeretik a hús ízét, fontosak számukra az előírások, a tápanyagtartalom, hogy gyermekeiknek megfelelő tápértékü ételt biztosítsanak. A közömbös húsfogyasztók 25 évnél fiatalabbak, nem lelik örömüket a húsfogyasztásban, de a kockázatokkal foglalkoznak. Az érdekelt húsevők figyelnek a fogyasztással kapcsolatos kockázatokra, családosok, kevesebbszer de inkább minőségi húst fogyasztanak és jellemzően hentestől vásárolnak.

Raimundo és Batalha (2015a, 2015b) a brazil sertés- és csirkehúspiac szegmentálását a húsfogyasztást és vásárlást befolyásoló faktorok alapján végezte el. Az eredmények azt mutatják, hogy a nagyvárosban élő válaszadók preferenciájában a marhahús (52\%) áll az első helyen, a csirkehús $(35 \%)$ a második és a sertéshús $(13 \%)$ a harmadik a sorban. A sertéshúsfogyasztás kapcsán három csoportot azonosítottak: a gazdaságos, a hagyományos és az igényes (Raimundo \& Batalha 2015a). Braziliában a $80^{\prime}$-as évek közepétöl jelentős mértékben nőtt a csirkehús fogyasztása, különösen a nők körében. A 413 válaszadó bevonásával készült primer kutatás során a csirkehús fogyasztására, annak helyettesítésére és a vásárlási körülményekre kérdeztek rá. Írországban a vörös és fehér, illetve feldolgozott húsok fogyasztásának gyakorisága (gramm/nap) alapján elemezték a tápanyagbevitelt (Cosgrove et al. 2005). A férfiak több húst (mindhárom hústípus esetén) fogyasztanak, mint a nők és fontos tápanyagokból, mint például a C-vitamin nem juttatnak elegendő mennyiséget a szervezetükbe.
Több kutatás is kitért a húsfogyasztással kapcsolatos etikai megfontolásokra (húsfogyasztás jogossága, állatok szenvedése). Joy (2011) koncepciója értelmében a húsevők nagy többsége húsfogyasztásuk indokát a négy N-re alapozza: természetes (natural), normális (normal), szükséges (necessary) és helyes (nice). Érvelésük szerint az ember mindenevő (természetes), az emberiség nagy része eszik húst (normális), a vegetáriánus étrendből hiányoznak tápanyagok (szükséges) és a hús jóizü (helyes). Az Amerikában élő különböző etnikumok bevonásával végzett kvantitatív kutatás (Piazza et al. 2015) igazolta, hogy a hús és húsból készült termékek fogyasztási gyakorisága és a $4 \mathrm{~N}$ koncepció alkalmazásával feltárt klaszterek (mindenevők, szemi-vegetáriánus, vegetáriánus, vegán) között szignifikáns kapcsolat áll fenn. Hoek és társai (2004) a Holland Nemzeti Élelmiszerfogyasztás Felmérés eredményeit felhasználva szocio-demográfiai ismérvek, egészségtudatosság és az ételhez kapcsolódó attitűdök alapján profilozták a holland vegetáriánusokat, nem vegetáriánusokat, a húshelyettesítő termékeket választókat és a húsfogyasztókat. A legnagyobb különbségeket az élelmiszerfogyasztáshoz kapcsolódó attitűdöknél (vásárlás, minőségi szempontok, főzési módszerek, fogyasztási helyzet, vásárlási motivációk) kapták a vegetáriánus és a húsfogyasztók között.

Több tanulmány is vizsgálta a gyerekeket (Smith et al. 2011), illetve a tinédzsereket (Honaken et al. 2004). Nagy-Britanniában 57 élelmiszercsoport fogyasztásának gyakorisága alapján azonosították a feldolgozott élelmiszereket (gyorsételeket), a növényi alapú élelmiszereket (egészségtudatos) és a hagyományos brit ételeket (tradíciókat követők) fogyasztók csoportját (Smith et al. 2011). A norvég fiatalok esetében egy preferencia alapú szegmentálást hajtottak végre nevezetesen, hogy a különbözö halas, húsos és modern ételeket mennyire kedvelik a tinik. A szegmensek jellemzésére a demográfiai ismérveken túl életstílusbeli jellemzőket és az attitủdöt is bevonták (Honaken et al. 2004).

Jelen kutatás empirikus részének célja hazánk fejlett (Nyugat-Dunántúl，Közép-Magyarország) térségeiben élő lakosok étkezési szokásának megismerése és a hús szerepének feltárása a mindennapokban, az alábbi kérdések mentén:

- Mi jellemző az emberek étkezésére? Hányszor étkeznek egy nap?

- Milyen szerepet kap a hús a mindennapi étkezésben?

- Nassolnak-e az étkezések között? 
- Elvégezhetö-e a fogyasztók szegmentálása az étkezések gyakorisága, valamint a húsfogyasztás és a nassolás gyakorisága alapján?

- Milyen szocio-demográfiai ismérvekkel rendelkeznek az azonosított fogyasztói csoportok?

A kutatási kérdések megválaszolásához a naplóíás módszerét alkalmaztuk. A kutatás lefolytatásában egyetemi hallgatók vettek részt, akik egy-egy ismerősüket arra kértek, hogy egy héten át jegyzetelje le, hogy mikor, mit és hol ettek, illetve az étkezések között nassoltak-e. Az empirikus kutatás 2017 áprilisában zajlott hazánk legfejlettebb régióiban (Nyugat-Dunántúl: 66,7\%, KözépDunántúl és Közép-Magyarország: 33,3\%), ahol a szekunder kutatás eredményei alapján a legkevesebb húst fogyasztják éves szinten. 171 fogyasztót sikerült elérni, 64,9\%-ban nőket, 35,1\%-ban férfiakat. Életkor alapján a legfiatalabb válaszadó 15 éves, a legidősebb 58 éves volt, az átlagéletkor 27,5 év, a szórás pedig 12,4 év, a legtöbben (módusz) 20 évesek, a medián pedig 22 év. Életkori kategóriák alapján az egyének 76,5\%-a fiatal (15-34 év), 15,9\%-a középkorú (35-50 év) és 7,6\%-a 50 év feletti szenior. A fogyasztók 30,4\%-a falun, 38,0\%-a városban, 29,2\%-a megyeszékhelyen és csupán 2,3\%-a a fővárosban él. Képzettség alapján 12\% alapfokú, 68,3\% középfokú (érettségi) és $19,8 \%$ felsőfokú iskolai végzettségü.

Az eredmények interpretálásához egy- és többváltozós statisztikai módszereket alkalmaztunk. Az első három kutatási kérdés megválaszolásához (étkezés, húsfogyasztás, nassolás) egyváltozós statisztikákra hagyatkoztuk. A fogyasztással kapcsolatos szocio-demográfiai összefüggéseket varianciaelemzéssel teszteltük. E statisztikai összefüggés elvégzéséhez szükséges egyik feltétel a szóráshomogenitás, azaz a függő változó (étkezések száma egy héten) szórásának azonosnak kell lennie a független változók (demográfiai ismérvek) minden szintjénél. Ennek tesztelésére a Levenetesztet használtuk, melynek nullhipotézise az, hogy a szórások egyelőek. A negyedik kutatási kérdés megválaszolásához klaszterelemzést futattunk le, ahol a hierarchikus, azon belül is az összevonó,
Ward-féle eljárással azonosítottuk a fogyasztói csoportokat étkezési, húsfogyasztási és nassolási gyakoriság alapján. Mivel az eltérések hangsúlyozása volt a célunk, ezért a távolságok mérésére a négyzetes euklideszi távolságot használtuk. $\mathrm{Az}$ előfeltételek vizsgálata után, több lehetőség figyelembe vételével négy klasztert azonosítottunk, majd ezek a klaszterek később, mint nominális szintú változók képezték a további vizsgálat alapját. A klaszterelemzés érvényességének tesztelése érdekében a nem hierarchikus klaszterelemzést, nevezetesen a K-közép klasztert is lefuttattuk. Így az eredmények általánosíthatók a vizsgált minta esetében. Végezetül az egyes klaszterek profilozását multinominális logisztikus regresszióelemzés segítségével végeztük el, hiszen több nemzetközi kutatás is e módszert alkalmazta (Honaken et al. 2004, Smith et al. 2011, Hoek et al. 2004)

\section{EREDMÉNYEK RESULTS}

\section{Étkezési szokások Eating habits}

A megkérdezettek $77,8 \%$ eszik reggelit, a legtöbben szombaton, a legkevesebben pedig szerdán. A tízórait fogyasztók aránya viszonylag alacsony $(41,9 \%)$. A hétvégén általában csak kevesen iktatják be ezt az étkezést. Ebédet többnyire mindenki fogyaszt $(95,7 \%)$, vasárnap senki sem hagyja ki ezt a fó étkezést. Az uzsonnázás a vizsgált alanyok mintegy harmadára jellemző, vacsorát pedig szintén nagy arányban fogyasztanak (1. táblázat). 


\section{1. táblázat: Az étkezések gyakorisága napi bontásban}

Table 1. Eating frequency on a daily basis

\begin{tabular}{|l|c|c|c|c|c|c|c|c|}
\hline & Hétfö & Kedd & Szerda & Csütörtök & Péntek & Szombat & Vasárnap & Átlag \\
\hline Reggeli & $77,8 \%$ & $80,7 \%$ & $74,3 \%$ & $74,9 \%$ & $76,0 \%$ & $82,5 \%$ & $78,4 \%$ & $77,8 \%$ \\
\hline Tízórai & $55,6 \%$ & $49,1 \%$ & $48,5 \%$ & $50,3 \%$ & $42,1 \%$ & $27,5 \%$ & $19,9 \%$ & $41,9 \%$ \\
\hline Ebéd & $95,3 \%$ & $93,6 \%$ & $94,7 \%$ & $93,0 \%$ & $95,3 \%$ & $98,2 \%$ & $100,0 \%$ & $95,7 \%$ \\
\hline Uzsonna & $34,5 \%$ & $35,1 \%$ & $31,0 \%$ & $32,7 \%$ & $30,4 \%$ & $30,4 \%$ & $33,3 \%$ & $32,5 \%$ \\
\hline Vacsora & $90,6 \%$ & $93,0 \%$ & $90,1 \%$ & $91,2 \%$ & $88,9 \%$ & $86,5 \%$ & $87,1 \%$ & $89,6 \%$ \\
\hline
\end{tabular}

Forrás: saját kutatás

A többség minden nap eszik reggelit. Tízórait és uzsonnát a többség nem fogyaszt, viszont reggelit, ebédet ás vacsorát igen. A naplóírást végző személyek átlagosan 23,63-szor esznek egy héten, a szórás $(4,99)$ meglehetősen nagy, tehát van, aki ennél öt alkalommal kevesebbszer és van aki, ennyivel többel. A medián 22 a módusz pedig 21, vagyis az étkezések heti száma normál eloszlást követ. Varianciaelemzés lefuttattatásával teszteltük, hogy milyen összefüggés van az étkezések mértéke és a szocio-demográfiai háttérváltozók között. Statisztikailag szignifikáns eredmény egyetlen esetben sem mutatható ki.

\section{A hús szerepe a mindennapi étkezésben The role of meat in everyday food consumption}

A továbbiakban azt vizsgáltuk, hogy azok, akik fogyasztanak reggelit, tízórait, ebédet, uzsonnát vagy vacsorát, milyen arányban esznek húst. A húsfogyasztás egyértelmủen az ebédre (75,9\%) és a vacsorára $(59,6 \%)$ koncentrálódik $(59,6 \%)$. Reggelire $(33,9 \%)$, tízóraira $(31,8 \%)$ és uzsonnára $(24,5 \%)$ viszonylag kevesen esznek húst (2. táblázat).

2. táblázat: A hús szerepe az étkezésekben

Table 2. The role of meat in food consumption

\begin{tabular}{|l|c|c|c|c|c|c|c|c|}
\hline & Hétfó & Kedd & Szerda & Csütörtök & Péntek & Szombat & Vasárnap & Átlag \\
\hline Reggeli & $36,1 \%$ & $28,3 \%$ & $33,1 \%$ & $42,2 \%$ & $28,5 \%$ & $34,0 \%$ & $34,8 \%$ & $33,9 \%$ \\
\hline Tízórai & $42,7 \%$ & $38,1 \%$ & $34,9 \%$ & $30,2 \%$ & $29,2 \%$ & $21,3 \%$ & $26,5 \%$ & $31,8 \%$ \\
\hline Ebéd & $77,9 \%$ & $75,0 \%$ & $67,3 \%$ & $70,4 \%$ & $71,2 \%$ & $79,2 \%$ & $90,1 \%$ & $75,9 \%$ \\
\hline Uzsonna & $30,5 \%$ & $26,7 \%$ & $28,3 \%$ & $32,1 \%$ & $19,2 \%$ & $17,3 \%$ & $17,2 \%$ & $24,5 \%$ \\
\hline Vacsora & $65,8 \%$ & $57,2 \%$ & $51,9 \%$ & $61,5 \%$ & $55,9 \%$ & $65,5 \%$ & $59,7 \%$ & $59,6 \%$ \\
\hline
\end{tabular}

Forrás: saját kutatás

A kutatásban résztvevők jellemzően ebédre és vacsorára fogyasztanak húst. A naplóírást végző személyek átlagosan 12,22-szor esznek egy héten, a szórás $(4,18)$ meglehetősen nagy, tehát van, aki ennél négy alkalommal kevesebbszer és van aki, ennyivel többel. A medián 12 a módusz pedig 11, vagyis húsfogyasztás heti száma normál eloszlást követ.
Varianciaelemzés lefuttattatásával teszteltük, hogy milyen összefüggés van a húsfogyasztás mértéke és a szocio-demográfiai háttérváltozók között. Statisztikailag szignifikáns eredmény nemek alapján született, hiszen a nők $(11,00)$ jóval kevesebb alkalommal esznek húst egy héten, mint a férfiak $(14,48)$. A kapcsolat erőssége gyenge (3. táblázat). 
3. táblázat: A heti húsfogyasztás gyakorisága nemek alapján

Table 3. The frequency of meat consumption based on gender

\begin{tabular}{|l|c|c|c|c|c|}
\hline \multicolumn{1}{|c|}{ Nem } & Átlag & N & Szórás & Minimum & Maximum \\
\hline Nö & 11,00 & 111 & 3,41 & 2,00 & 22,00 \\
\hline Férfi & 14,48 & 60 & 4,52 & 7,00 & 29,00 \\
\hline Összesen & 12,22 & 171 & 4,18 & 2,00 & 29,00 \\
\hline
\end{tabular}

Megjegyzés: $F=31,87 ; p=0,00 ; \eta 2=0,159$

Forrás: saját kutatás

\section{Nassolás \\ Snacking}

Vizsgáltuk, hogy a kutatásba vont egyének egy héten hányszor nassolnak: $11,1 \%$ egyáltalán nem, a többség (24\%) viszont minden nap. A hétvégen (szombat: 55\%; vasárnap: 61,4\%) jellemzően többet nassolnak, mint hétköznap (hétfő: $55 \%$, kedd: 52,6\%, szerda: $45,6 \%$, csütörtök: $54,4 \%$, péntek: $53,8 \%$ ). A megkérdezettek fele háromnál kevesebbszer, míg a másik fele ennél többször nassol egy héten. Varianciaelemzés lefuttattatásával teszteltük, hogy milyen összefüggés van a nassolás mértéke és a szocio-demográfiai háttérváltozók között. Statisztikailag szignifikáns eredmény az iskolai végzettség esetében született, hiszen az alapfokú iskolai végzettségüek $(5,30)$ jóval többször nassolnak egy héten, mint a közép- $(3,76)$ vagy felsőfokú $(2,54)$ végzettségüek. A kapcsolat erőssége gyenge (4. táblázat).

\section{4. táblázat: A nassolás mértéke iskolai végzettség alapján}

Table 4. Snacking based on the level of education

\begin{tabular}{|l|c|c|c|c|c|}
\hline Iskolai végzettség & Átlag & $\mathbf{N}$ & Szórás & Minimum & Maximum \\
\hline alapfokú & 5,3000 & 20 & 2,25015 & 0 & 7 \\
\hline középfokú & 3,7632 & 114 & 2,22735 & 0 & 7 \\
\hline felsőfokú & 2,5455 & 33 & 2,09301 & 0 & 7 \\
\hline Összesen & 3,7066 & 167 & 2,31889 & 0 & 7 \\
\hline
\end{tabular}

Megjegyzés: $F=9,84 ; p=0,00 ; \eta 2=0,107$

Forrás: saját kutatás

\section{Szegmentálás}

\section{Segmentation}

A heti étkezés ${ }^{2}$, a húsfogyasztás ${ }^{3}$ és a nassolás relatív gyakorisága alapján klaszterelemezést végzünk. A klaszteranalízis felettébb érzékeny a kiugró adatokra (Sajtos - Mitev 2007), ezért első lépésként azokat vizsgáltuk. A nem egyforma mérési szintü változók miatt skálatranszformációt hajtottunk végre, hogy arányokkal, százalékos értékekkel dolgozzunk.

A korreláció vizsgálatával ellenőriztük, hogy a vizsgálatba bevont változók között nincs nagyon erős ( 0,9 feletti) korreláció, ezért ez sem befolyásolta a kiindulási feltételeket. A mintából a klaszterelemzésbe 171 fö́t sikerült bevonni. A megfi- gyelési egységek távolságának (mivel a célunk az eltérések hangsúlyozása) vizsgálatára a négyzetes euklideszi távolságot használtuk. A hierarchikus klaszterelemzésen belül az összevonó algoritmust és azon belül a Ward féle eljárást használtuk. Mind a könyökkritérium, mind az összevonási séma vizsgálata négyklaszteres megoldást eredményezi. Ebben az esetben kiegyenlített az egy klaszterbe tartozó egyének száma: 1. klaszter 47 fö (27,5\%), 2. klaszter 30 fó $(17,5 \%)$, a 3. klaszter 60 fö $(35,1 \%)$ és a 4. klaszter 34 fó $(19,9 \%)$. A klaszterek tipologizálásához az átlagok vizsgálata szükséges. Varianciaelemzéssel ellenőrizzük, hogy a csoportok a vizsgált változók esetében eltérő csoportátlaggal jellemezhetőek, azaz a köztük lévő különbség szignifikáns. Post Hoc tesztekkel vizsgálva a csoportok 
átlagainak egymáshoz való viszonyát, minden esetben statisztikailag szignifikáns eltéréssel találkozunk. Az eredmények alapján kijelenthetjük, hogy a meghatározott csoportok egymástól a vizsgált változók alapján jól elkülöníthető szegmenseket alkotnak (5. táblázat).

\section{5. táblázat: A vizsgált jellemzők csoportátlagai klaszterenként Table 5. Mean of the analyzed variables based on cluster membership}

\begin{tabular}{|l|c|c|c|c|}
\hline \multicolumn{1}{|c|}{ Csoport elnevezés } & $\mathbf{N}$ & Étkezés aránya & $\begin{array}{c}\text { Húsfogyasztás aránya } \\
\text { az étkezésen belül }\end{array}$ & $\begin{array}{c}\text { Nassolás } \\
\text { gyakorisága }\end{array}$ \\
\hline 1. visszafogott húsfogyasztók & 47 fó & $\begin{array}{c}75,08 \% \\
(\mathrm{SD}=13,82 \%)\end{array}$ & $\begin{array}{c}42,82 \% \\
(\mathrm{SD}=13,58 \%)\end{array}$ & $\begin{array}{c}44,07 \% \\
(\mathrm{SD}=13.59 \%)\end{array}$ \\
\hline 2. tudatosan étkezők & 30 fó & $\begin{array}{c}69,52 \% \\
(\mathrm{SD}=15,01 \%)\end{array}$ & $\begin{array}{c}51,42 \% \\
(\mathrm{SD}=17,90 \%)\end{array}$ & $\begin{array}{c}5,71 \% \\
(\mathrm{SD}=8,04 \%)\end{array}$ \\
\hline 3. nassolók & 60 fó & $\begin{array}{c}66,38 \% \\
(\mathrm{SD}=13,82 \%)\end{array}$ & $\begin{array}{c}55,74 \% \\
(\mathrm{SD}=15,88 \%)\end{array}$ & $\begin{array}{c}92,14 \% \\
(\mathrm{SD}=12,45 \%)\end{array}$ \\
\hline 4. húsimádók & 34 fó & $\begin{array}{c}57,31 \% \\
(\mathrm{SD}=6,81 \%)\end{array}$ & $\begin{array}{c}61,26 \% \\
(\mathrm{SD}=9,28 \%)\end{array}$ & $\begin{array}{c}42,86 \% \\
(\mathrm{SD}=11,12 \%)\end{array}$ \\
\hline
\end{tabular}

Forrás: saját kutatás

Az elsö csoport tagjai figyelnek a legjobban a napi ötszöri étkezésre, hiszen 75\%-ban teljesítik az ajánlott irányelvet. Ök fogyasztják a legkevesebb húst, és az étkezések között kevésbé nassolnak. Táplálkozásukra és azon belül is a húsfogyasztásukra a visszafogottság jellemző, ezért ők a visszafogott húsfogyasztók.

A második csoportban vannak azok, akik közel 70\%-ban teljesítik a napi ötszöri ételfogyasztást, az étkezéseik mintegy fele tartalmaz húst. Nagyon ritkán nassolnak, ezért ők a tudatosan étkezök.

A harmadik csoport tagjai kevesebbszer étkeznek egy nap, viszont minden második alkalommal esznek húst és szinte minden nap nassolnak az étkezések között, ezért ők a nassolók.

A negyedik csoportba tartozók követik legkevésbé a napi öt étkezés elvet, ők fogyasztják a legtöbb húst és a nassolás ugyan jelen van, de nem meghatározó, ezért ők a húsimádók.

A klaszterek profilozása multinominális logisztikus regresszióelemzés segítségével történt, ahol függő változó a klasztertagság, független változók pedig a szocio-demográfiai ismérvek (nem, lakhely, régió, életkor és iskolai végzettség). Cél azonosítani azokat a tényezőket, amelyek szignifikánsan megkülönböztetik az egyes klasztereket, illetve ellenőrizni, hogy a csoporthoz való tartozás becsülhetö-e az említett független változókkal és milyen arányban. A modell illeszkedése megfelelö, hiszen a Pearson féle $\chi^{2}$ értéke 322,279, $\mathrm{p}=0,003$. A Nagelkerke $R^{2}$ értéke 0,374 , vagyis a független változók 37,4\%-ban magyarázzák a függő változók alakulását. Az öt szocio-demográfiai ismérv közül csupán kettőnek van szignifikáns hatása a klasztertagságra, mégpedig a nemnek $(\mathrm{p}=0,024)$ és az iskolai végzettségnek $(\mathrm{p}=0,001)$. Amennyiben a húsimádókat vesszük referenciának, a paraméterbecslés alapján a következő megállapításokat tehetjük:

- A nők a férfiakhoz képest inkább visszafogott húsfogyasztók csoportjába tartoznak, mintsem húsimádók közé $(\beta=1,51)$.

- A falvakban élők a megyeszékhelyen élőkhöz képest inkább a tudatosan étkezők csoportjába tartoznak, mintsem a húsimádók közé $(\beta=16,41)$.

- A városban élők a megyeszékhelyen élőkhöz képest inkább a tudatosan étkezők csoportjába tartoznak, mintsem a húsimádók közé $(\beta=16,00)$.

- A falvakban élők a megyeszékhelyen élőkhöz képest inkább a nassolók csoportjába tartoznak, mintsem a húsimádók közé $(\beta=16,32)$.

- A városban élők a megyeszékhelyen élőkhöz képest inkább nassolók csoportjába tartoznak, mintsem a húsimádók közé $(\beta=16,36)$.

- $\quad$ Az alapfokú iskolai végzettségűek a diplomásokhoz képest inkább a nassolók csoportjába tartoznak, mintsem a húsimádók közé $(\beta=3,52)$. 
- Amennyiben az egyes fogyasztói csoportokat akarjuk szocio-demográfiai ismérvek alapján jellemezni, akkor kijelenthetjük, hogy a visszafogott húsevők inkább nők, a tudatosan étkezők jellemzően falvakban és városokban laknak, csakúgy, mint a nassolók, akik alapfokú iskolai végzettségűek.

\section{KÖVETKEZTETÉSEK, JAVASLATOK CONCLUSION, SUGGESTION}

Empirikus kutatásunk rávilágított arra, hogy hazánk legfejlettebb régióiban élők számára kevésbé jellemző a napi ötszöri étkezés, előfordul, hogy egyegy fóétkezést kihagynak, illetve hétvégén többször esznek. Törőcsik és Pál (2015) eredményeihez hasonlóan kijelenthetjük, hogy a rendszertelen étkezés hódít teret, viszont az ebéd és a vacsora a legfontosabbak. A hús a napi étkezések része, bár a fogyasztási alkalmak számát tekintve jelentős eltérések adódtak, különösen nemek alapján. Hazánkban is igaz, hogy a húsfogyasztás inkább maszkulin tevékenység (Dagevos \& Voordouw 2013). A nassolás a hétvégi időpontokra jellemzőbb és összefüggést mutat az alacsonyabb iskolai végzettséggel. Több hazai nemzetközi kutatás is foglalkozott a fogyasztók klaszterezésével, szegmentálásával. Marketing szempontból fontos egyegy homogén fogyasztói csoport ismerete és célzott elérése. A szakirodalom-feldolgozás részben több nemzet kutatási eredményét foglaltuk össze és kijelenthetjük, hogy nagyon széles a skála a nézőpontokban. Vizsgálták az attitüdöket (Dernóczy-Polyák - Keller 2016, 2018), az etikai megfontolásokat (Piazza et al. 2015), az érintettséget (Verbeke \& Vackier 2004), a vásárlási szokásokat (Raimundo \& Batalha 2015) a fogyasztási gyakoriságot (Dagevos \& Voordouw 2013, Smith et al. 2011), a preferenciát (Honaken et al. 2004) és a tápanyagbevitelt (Cosgrove et al. 2005). Jelen kutatás az étkezés, a húsfogyasztás és a nassolás gyakoriságára koncentrált. Négy fogyasztói csoportot azonosítottunk. A visszafogott húsfogyasztók táplálkozására a mértékletesség jellemző. A tudatosan étkezők többször esznek, egyúttal húst és húskészítményt is, viszont nem nassolnak. Valószínüleg ők azok, akik egészségtudatosak, figyelnek arra, hogy mit és mikor, illetve mennyit esznek. Tudatosságukból fakadóan minden olyan hústermék, ami minőségi, adalékanyagmentes jó lehet a számukra. A marketingkommunikációs tevékenységben is a hasznosságot, az egészségességet kell kiemelni. A nassolók esetében a társadalmi célú kampányok vagy üzenetek lehetnek hatékonyak, hiszen őket érdemes lenne az étkezések közötti „felesleges kalóriabevitel” helyett a fóétkezések felé terelni. A húsimádók nagy valószínűséggel hedonisták, akik szeretnek enni, húst fogyasztani és nassolni. Számukra érdemes lenne a különleges húsokat, vadhúsokat, mindenféle ínyenc termékeket kínálni és népszerüsíteni.

A kutatásnak számos korlátja van, hiszen egy bizonyos területegységre, régióra koncentráltunk az adatfelvétel során, illetve a fiatalok voltak többségben. Jelen tanulmányban nem tértünk ki az étkezések helyszínének bemutatására, illetve az elfogyasztott hús típusának elemzésére.

A jövőben érdemes lehet összefüggést vizsgálni a klasztertagság és az elfogyasztott hús típusa (vörös, fehér, feldolgozott) között. Továbbá a kutatás kiterjesztéseként érdemes lenne további életstílus-és attitüdbeli tényezö bevonása, nevezetesen az egészségtudatosság és az élelmiszerfogyasztáshoz kapcsolódó vélemények bevonása. Érdekesnek tartjuk a nassolási szokások alaposabb vizsgálatát, nem csupán napi szinten, hanem az étkezések között alkalmakra lebontva, továbbá annak menynyiségét és típusát.

\section{ÖSSZEFOGLALÁS SUMMARY}

Hazánkban a hús egy nagyon fontos élelmiszerforrás, éves szinten több mint $60 \mathrm{~kg}$-ot fogyasztunk belőle. A tanulmány célja hazánk fejlett régióiban élő lakosok étkezési szokásának megismerése és a hús szerepének feltárása a mindennapokban felhasználva egy héten keresztül vezetett étkezési naplók adatait. A vizsgált egyének számára az ebéd és a vacsora a legfontosabb étkezés, az ajánlott napi ötszöri étkezést csupán kevesen tartják be. A hús fontos a mindennapi étkezések alkalmával, bár a nök kevesebbszer fogyasztanak húst, mint a férfiak. A nassolás jelen van az emberek mindennapjaiban, főként az alacsonyabb iskolai végzettségüek körében. A heti étkezés, a húsfogyasztás és a nassolás gyakorisága alapján klaszterelemezést végzünk. Négy fogyasztói szegmenst azonosítottunk: a viszszafogott húsevők, a tudatosan étkezők, a nassolók és a húsimádók csoportját. A visszafogott húsevők inkább nők, a tudatosan étkezők jellemzően falvakban és városokban laknak, csakúgy, mint a nassolók, akik alapfokú iskolai végzettségüek. A kutatás eredményei hasznosak lehetnek az élelmiszeripar, különösen a húsipari vállalatok számára, hogy célzott marketingkampánnyal és termékekkel érjék el a fogyasztókat. 
${ }^{1}$ Marha és borjúhús: $1 \mathrm{~kg}$; sertés: 17 kg; baromfi: 20 kg; szalámi, szárazkolbász, sonka: 8,4 kg; egyén hentesáru: 9,4 kg; belsőség: $2,7 \mathrm{~kg}$; juh, kecske, nyúl és egyéb: $0,1 \mathrm{~kg}$.

$$
\begin{aligned}
& { }^{2} x(\%)=\frac{\text { étkezések száma egy héten }}{35(5 \times 7)} ; \text { átlag }=67,52 \% \text {; szórás }=14,25 \% \\
& { }^{3} x(\%)=\frac{\text { húsose ételek fogyasztása egy héten }}{\text { étkezések száma egy héten }} \text { átlag }=52,53 \% \text {; szórás }=15,93 \% \\
& { }^{4} x(\%)=\frac{\text { nassolás számaegy héten }}{7(1 \times 7)} ; \text { átlag }=53,97 \% \text {; szórás }=33,40 \%
\end{aligned}
$$

\section{HIVATKOZÁSOK REFERENCES}

OECD (2019), Agricultural output - Meat consumption - OECD Data, https://data.oecd.org/ agroutput/meat-consumption.htm (Letöltés ideje: 2019.03.12.)

KSH (2017), Az egy före jutó éves élelmiszer-fogyasztás mennyisége jövedelmi tizedek (decilisek), régiók és a települések típusa szerint, http:// www.ksh.hu/docs/hun/xstadat/xstadat eves/i zhc023b.html?down $=8000$ (Letöltés ${ }^{-}$ideje: 2019.03.12.)

Cosgrove, M., Flynn, A. and Kiely, M. (2005), “Consumption of red meat, white meat and processed meat in Irish adults in relation to dietary quality", British Journal of Nutrition, 93(1), 933-942. DOI: $10.1079 /$ bjn20051427

Dagevos, H. and Voordouw, J. (2013), "Sustainability and meat consumption: Is reduction realistic?", Sustainability: Science, Practice, \& Policy, 9(2), 1-10. DOI: 10.1080/15487733.2013.11908115

Dernóczy-Polyák A., Keller V. (2016), „A fehér, a vörös, a mindkettő és az egyik sem - klaszterek a húsfogyasztás alapján", In: Fehér A., Kiss V. Á., Soós M., Szakály Z. (szerk.), Hitelesség és Értékorientáció a Marketingben, EMOK 2016 Tudományos Konferencia konferenciakötete, Debreceni Egyetem Gazdaságtudományi Kar: Debrecen, 319-329

Dernóczy-Polyák A., Keller V. (2018), „Attitűd alapú szegmentálás a MAQ skála alapján”, In: Józsa L., Korcsmáros E., Seres Huszárik E. (szerk.), $A$ hatékony marketing, EMOK 2018 Nemzetközi Tudományos Konferencia konferenciakötete. Selye János Egyetem: Komárom, 721-731

Fehér A., Szakály Z. (2017), „Húsipari marketing”, in: Szakály Z. (szerk.) Élelmiszermarketing, Budapest: Akadémiai Kiadó, 440-447

Hoek, A. C., Luning, P. A., Stafleu, A. and Graaf, C. (2004), "Food related lifestyle and health attitudes of Dutch vegetarians, non-vegetarian consumers of meat substitutes, and meat consumers". Appetite, 42(1), 265-272. DOI: 10.1016/j. appet.2003.12.003

Honaken, P., Olsen, S. O. and Myrland, Ø. (2004), "Preference-based segmentation: A study of meal preferences among Norwegian teenagers", Journal of Consumer Behaviour, 3(3), 235-250. DOI: 10.1002/cb. 137

Joy, M. and J. Robbins (2011), Why We Love Dogs, Eat Pigs, and Wear Cows: An Introduction to Carnism, USA: Conari Press
Marlow, H., Hayes, W., Soret, S., Carter, R., Schwab E. and Sabaté, J. (2009), "Diet and the environment: does what you eat matter?", American Journal of Clinical Nutrition, 89(5), 1699-1703. DOI: 10.3945/ajen.2009.26736Z

Nábrádi Zs., Kovács S., Szakály Z. (2017), „Húsfogyasztási szokások összefüggése az evési attitüdökkel a fiatal felnőtt korosztályban", Marketing \& Menedzsment, 51(EMOK különszám), $75-84$

Piazza, J., Ruby, M. B., Loughnan, S., Luong, M., Kulik, J., Watkins, H. M. and Seigerman, M. (2015), "Rationalizing meat consumption: The 4Ns", Appetite, 91(1), 114-128. DOI: 10.1016/j. appet.2015.04.011

Raimundo, L. M. B. and Batalha, M. O. (2015a), "Swine meat market in Sao Paulo: segments and strategies", Gestão \& Produção, 22(2), 391-403. DOI: $10.1590 / 0104-530 X 1240-14$

Raimundo, L. M. B. and Batalha, M. O. (2015b), "Consumption of chicken meat in Sao Paulo: market segmentation and strategies", Conference: 9èmes Journées de Recherches en Sciences Sociales. SFER-INRA-CIRAD, At Nancy, France, 9(1), 1-14

Sajtos L., Mitev A. (2007), SPSS kutatási és adatelemzési kézikönyv, Budapest: Alinea Kiadó

Smith, A. D. A. C., Emmett, P. M., Newby, P. K. and Northstone, K. (2011), "A comparison of diatary patterns derived by cluster and principal components analysis in a UK cohort of children", European Journal of Clinical Nutrition, 65(1), 1102 1109. DOI: $10.1038 /$ ejen.2011.96

Törőcsik M., Pál E. (2015), „Napjaink ételfogyasztói magatartásának ismertetése, különös tekintettel a megváltozott étkezési ritmusra és a reggeli fogyasztásra", In: Dr. Bíró-Szigeti Sz., Petruska I., Szalkai Zs., Kovács I., Magyar M. (2015), Marketing hálózaton innen és túl, Az Egyesület a Marketing Oktatásért és Kutatásért XXI. országos konferenciájának tanulmánykötete, Budapesti Müszaki és Gazdaságtudományi Egyetem: Budapest, 90-101

Tukker, A., Goldbohm, A. R., De Koning, A., Verheijden, M., Kleijn, R., Wolf, O., Pérez-Domínguez, I. and Rueda-Cantuche, J. (2011), "Environmental impacts of changes to healthier diets in Europe", Ecological Economics, 70(10), 17761788. DOI: 10.1016/j.ecolecon.2011.05.001

Verbeke, W. and Vackier, I. (2004), "Profile and effects of consumer involvement in fresh meat", Meat Science, 67(1), 159-168. DOI: 10.1016/j. meatsci.2003.09.017 


\section{Keller Veronika, egyetemi docens}

kellerv@sze.hu

Ercsey Ida, egyetemi docens ercsey@sze.hu

Széchenyi István Egyetem Kautz Gyula Gazdálkodástudományi Kar Marketing és Menedzsment Tanszék

\section{Meat consumption behavior based on the experience of a food diary}

\section{THE AIMS OF THE PAPER}

Meat is an important source of nutrient for Hungarian since considering food consumption meat is the fourth most important one. The aim of this study is to explore of eating habits and the role of meat in everyday life and to segment consumers based on meat consumption and snacking and to profile them based on socio-demographics.

\section{METHODOLOGY}

Ton answer the research questions the method of diary was used. Participant had to note their eating habits, what they ate, when and where and whether they snacked between meal times or not. The empirical research was conducted in April 2017 in the most developed regions of Hungary (Western Transdanubia: $66.7 \%$, Central Transdanubia and Central Hungary: 33.3\%). Altogether the data of $171(66.7 \%$ females and $35.1 \%$ males) consumers were collected. To interpret the results uni- and multivariate statistical analysis was used. The connection between consumption and socio-demographics was analysed with the method of ANOVA. To segment consumers the methods of hierarchical (Ward's method) and non-hierarchical cluster analyses (K-mean) were used. To profile each segment the multinominal logistic regression was conducted.

\section{MOST IMPORTANT RESULTS}

Lunch and dinner are the most important eating occasions among participants. Only a few people follow a healthy diet and eat five times a day. Meat is an important nutrition in every-day eating however females eat less than males. Snacking is also typical for Hungarian especially for those who have lower level of education. Cluster analysis was conducted based on the frequency of eating, meat consumption and snacking. Four consumer groups were identified: restrained meat eaters, conscious eaters, snack lovers and meat lovers. Restrained meat eaters are mainly females. Conscious eaters live in villages or towns like snack lovers who typically have lower level of education.

\section{RECOMMENDATIONS}

These results are useful for food especially meat industry to define their marketing program and product policy targeted at special audience.

Keywords: meat consumption, snacking, segmenting

Acknowledgement: This work was supported by Széchenyi István University and the Hungarian Government and the European Union within the European Structural and Investment Funds. This study was written as a part of a project entitled EFOP-3.6.1-16-2016-00017, "Internationalization, initiatives to establish a new source of researchers and graduates, and development of knowledge and technological transfer as instruments of intelligent specializations at Szechenyi University". 